\title{
Efikasi diri mahasiswa pada perkuliahan kalkulus integral
}

\author{
Mega Eriska Rosaria Purnomo *, Christina Kartika Sari, Sri Rejeki, Isnaeni Umi Machromah \\ Program Studi Pendidikan Matematika, Fakultas Keguruan dan Ilmu Pendidikan, Universitas \\ Muhammadiyah Surakarta. Jalan A. Yani Tromol Pos I, Sukoharjo, 57102, Indonesia. \\ * Corresponding Author. E-mail: mega.eriska@ums.ac.id \\ Received: 27 August 2018; Revised: 26 October 2018; Accepted: 4 November 2018
}

\begin{abstract}
Abstrak
Penelitian kualitatif ini bertujuan untuk mendeskripsikan pofil efikasi diri mahasiswa pada perkuliahan Kalkulus Integral. Subjek penelitian adalah 43 mahasiswa Program Studi Teknik Industri Universitas Muhammadiyah Surakarta yang mengikuti perkuliahan Kalkulus Integral. Instrumen pengumpulan data terdiri dari angket efikasi diri serta pedoman wawancara. Subjek mengisi angket efikasi diri. Hasilnya adalah 2\% mahasiswa memiliki efikasi diri sangat tinggi, 40\% tinggi, 51\% sedang, $7 \%$ memiliki efikasi diri rendah. Selanjutnya dipilih 6 mahasiswa, masing-masing 2 mahasiswa dengan efikasi diri tinggi, sedang, rendah untuk diwawancarai. Hasilnya yaitu mahasiswa dengan efikasi diri tinggi dan sedang tidak putus asa dalam menyelesaikan permasalahan Kalkulus Integral, sedangkan mahasiswa dengan efikasi diri rendah putus asa saat menghadapi permasalahan tersebut. Mahasiswa dengan tingkat efikasi diri tinggi, sedang, dan rendah belum mampu mempelajari materi sulit Kalkulus Integral secara mandiri. Akan tetapi, mereka mampu menyelesaikan tugas dan mengumpulkannya tepat waktu. Usaha belajar mereka belum optimal dengan berbagai macam penyebab sehingga mereka tidak yakin mampu mencapai prestasi belajar yang ditargetkan, terkecuali dua mahasiswa dengan efikasi diri tinggi dan sedang.
\end{abstract}

Kata Kunci: efikasi diri, perkuliahan kalkulus integral

\section{Self-efficacy of university student in integral calculus course}

\begin{abstract}
This qualitative research aimed to describe students' self-efficacy profile on Integral Calculus course. The subjects were 43 students of Industrial Engineering Department, Universitas Muhammadiyah Surakarta, who attended Integral Calculus course. The instruments used to data collecting were self-efficacy questionnaire and interview guidelines. The subjects were given selfefficacy questionnaire. The results showed that $2 \%$ of students had very high of self-efficacy, $40 \%$ high, $51 \%$ middle, the remaining $7 \%$ students had low self-efficacy. Six students were selected to be interviewed, consisted of 2 students with high, middle, and low self-efficacy. The interview results were students with high and middle self-efficacy were not give up to solve Integral Calculus problems, while students with low self-efficacy tend to desperate when solving the problems. Students with high, middle, and low self-efficacy levels had not been able to study the Integral Calculus difficult material independently. However, they were able to complete the task and collect it on time. Their learning efforts have not been optimal with a variety of causes so they were not confident for reaching optimum achievement, except two students with high and middle self efficacy level.
\end{abstract}

Keywords: self-efficacy, integral calculus course

How to Cite: Purnomo, M., Sari, C., Rejeki, S., \& Machromah, I. (2018). Efikasi diri mahasiswa pada perkuliahan kalkulus integral. Jurnal Riset Pendidikan Matematika, $181-189$. doi:https://doi.org/10.21831/jrpm.v0i0.20271

Permalink/DOI: https://doi.org/10.21831/jrpm.v0i0.20271

\section{PENDAHULUAN}

Pada saat dihadapkan dengan materi kuliah maupun soal yang sulit, dijumpai mahasiswa yang cenderung menyerah dan kurang berusaha. Sementara ada pula mahasiswa yang merasa tertantang untuk memahami materi sulit serta terus berusaha memecahkan soal yang rumit. 
Salah satu aspek psikologis yang berpengaruh terhadap keberhasilan mahasiswa dalam perkuliahan adalah efikasi diri (self-efficacy) (Sopiyanti, 2011; Wijaya \& Pratitis, 2012)

Efikasi diri merujuk kepada keyakinan seseorang mengenai kemampuan dirinya untuk belajar atau melakukan sesuatu (Schunk, 2012, p. 146). Pajares dan Miller (Mercer, 2011, p. 15) menjelaskan bahwa efikasi diri adalah penilaian spesifik terhadap kompetensi yang harus ditunjukkan untuk melakukan tugas tertentu pada situasi spesifik. Dijelaskan pula oleh Pajares dan Miller bahwa efikasi diri matematika baru-baru ini menjadi perkiraan sejauh mana keputusan individu terhadap kemampuan mereka untuk memecahkan masalah matematika yang khusus, mengerjakan tugas yang berhubungan dengan matematika, atau keberhasilan dalam pembelajaran yang terkait dengan matematika.

Salah satu mata kuliah matematika di perguruan tinggi yang dianggap sulit adalah Kalkulus, meskipun materi-materi pada Kalkulus telah dipelajari oleh mahasiswa saat duduk di bangku sekolah menengah tingkat atas. Mata kuliah ini tidak hanya bagian dari bidang studi matematika saja, tetapi juga merupakan mata kuliah utama pada bidang teknik maupun ilmuilmu sosial (Sevimli, 2016, p. 1). Begitu juga dengan Kalkulus Integral. Mata kuliah ini menawarkan materi mengenai integral dari berbagai macam tipe fungsi serta berbagai macam aplikasinya. Mahasiswa teknik, khususnya teknik industri mempelajari ini sebagai bekal ilmu untuk menyelesaikan permasalahan pada bidang keteknikan.

Seorang mahasiswa seharusnya mampu menilai kemampuan diri sendiri secara akurat. Motlagh, Amrai, Yazdani, Abderahim, dan Sauri. (2011, p. 767) mengemukakan bahwa efikasi diri adalah faktor penentu dalam pencapaian prestasi akademik. Demikian pula Yusuf (2011, p. 2623) menyatakan bahwa keyakinan efikasi diri pada diri mahasiswa secara signifikan meningkatkan pencapaian hasil belajar. Apabila seseorang salah menilai kemampuannya, ia akan bertindak pada suatu cara tertentu yang akan merugikan dirinya sendiri (Irwansyah, 2013, p. 116). Jika mahasiswa menilai kemampuannya terlalu tinggi pada perkuliahan Kalkulus Integral, ia tidak akan mampu meraih target yang ditetapkan pada mata kuliah tersebut sehingga berdampak pada kegagalan. Sementara jika ia menilai kemampuannya terlalu rendah, ia akan membatasi diri untuk mencoba pengalaman belajar yang menantang.
Individu dengan efikasi diri tinggi akan membangun banyak kemampuan melalui usahausaha mereka, sementara individu dengan efikasi diri rendah akan memperlambat perkembangan dari kemampuan-kemampuan tersebut (Urdan \& Pajares, 2006, p. 339). Woolfolk (2007, p. 332) berpendapat efikasi diri timbul apabila individu mengerjakan tugas-tugas menantang dan bermakna dengan dukungan gurunya. Selain itu, efikasi diri juga dapat muncul dengan mengamati keber-hasilan individu yang mengerjakan tugas yang sama. Karenanya, saat menghadapi permasalahan Kalkulus Integral yang sulit, mahasiswa yang ragu terhadap kemampuan yang dimiliki cenderung enggan berusaha dan menyerah, sedangkan mahasiswa dengan efikasi diri tinggi menganggap permasalahan Kalkulus Integral yang sulit sebagai tantangan dan kegagalan dalam menye-lesaikan permasalahan tersebut bukan karena kurangnya kemampuan matematis tetapi karena kurangnya usaha yang dilakukan.

Putri, Mardiyana, dan Saputro (2017, p. 1) dalam penelitiannya mengemukakan bahwa dengan memberi perhatian pada efikasi diri, terutama pada proses pemecahan masalah, diharapkan pendidik dapat mempersiapkan pembelajaran dengan sebaik mungkin demi mencapai hasil pembelajaran yang optimal. Menurut Putri dan Santosa (2015, p. 262) salah satu strategi pembelajaran yang efektif pada materi kalkulus turunan fungsi ditinjau dari aspek efikasi diri adalah startegi pembelajaran REACT.

Penelitian oleh Jaafar dan Ayub (2010, p. $519)$ yang menyatakan bahwa terdapat hubungan positif antara performa matematika dengan efikasi diri matematis pada diri mahasiswa. Menurut penelitian Margolis dan McCabe (2006, p. 219) efikasi diri yang rendah menghambat pencapaian akademis. Suryadi dan Santoso (2017, p. 16) dalam hasil penelitiannya mengemukakan bahwa efikasi diri berkontribusi terhadap usaha yang lebih baik serta memiliki efek signifikan terhadap prestasi matematika.

Berdasarkan teori para ahli, maka indikator efikasi diri yang digunakan dalam penelitian ini adalah: (1) yakin dengan kemampuan diri, (2) mampu menyelesaikan permasalahan pada mata kuliah Kalkulus Integral, (3) mampu melaksanakan tugas pada perkuliahan, (4) mampu mencapai target prestasi belajar pada mata kuliah Kalkulus Integral, serta (5) yakin dengan usaha yang telah dilakukan.

Berdasarkan uraian tersebut, maka diperlukan suatu upaya untuk menganalisis pofil efikasi diri mahasiswa pada perkuliahan Kalkulus 
Integral. Oleh karena itu, penelitian ini bertujuan untuk mendeskripsikan pofil efikasi diri mahasiswa pada perkuliahan Kalkulus Integral. Adapun manfaat yang diperoleh dari penelitian ini yaitu dosen dapat memperoleh gambaran awal mengenai efikasi diri mahasiswa pada perkuliahan Kalkulus Integral, sehingga dapat dijadikan dasar pijakan bagi dosen untuk mengembangkan pembelajaran Kalkulus Integral yang interaktif dan menyenangkan sesuai dengan kondisi psikologis mahasiswa.

\section{METODE}

Penelitian ini merupakan penelitian kualitatif dengan strategi deskriptif. Pada penelitian ini, profil efikasi diri mahasiswa pada perkuliahan Kalkulus Integral dideskripsikan apa adanya, tanpa manipulasi maupun perlakuan tertentu.

Penelitian ini dilaksanakan pada bulan Maret-April 2018 bertempat di Universitas Muhammadiyah Surakarta (UMS). Sebanyak 43 mahasiswa Teknik Industri mengisi angket efikasi diri pada hari Rabu, tanggal 28 Maret 2018 di ruang kuliah Prodi Teknik Industri UMS. Selanjutnya, dipilih 6 mahasiswa untuk diwawancarai agar memperoleh data lebih mendalam mengenai efikasi diri mahasiswa. Kegiatan wawancara dilasanakan pada hari Sabtu tanggal 7 April 2018 bertempat di ruang dosen Prodi Pendidikan Matematika FKIP UMS.

Subjek penelitian ini adalah 43 mahasiswa Teknik Industri Universitas Muhammadiyah Surakarta yang mengikuti perkuliahan Kalkulus Integral pada tahun akademik 2017/2018. Selanjutnya dipilih 6 mahasiswa, terdiri atas masingmasing 2 mahasiswa dengan efikasi diri tinggi, sedang, dan rendah berdasarkan hasil angket efikasi diri untuk diwawancarai agar memperoleh data lebih mendalam.

Kegiatan-kegiatan yang dilakukan dalam penelitian ini yaitu: (1) melakukan pengamatan terhadap kondisi mahasiswa dan proses perkuliahan Kalkulus Integral di kelas. Ternyata, salah satu aspek psikologis yang mempengaruhi keberhasilan mahasiswa dalam perkuliahan adalah efikasi diri, (2) 43 mahasiswa Teknik Industri yang mengikuti perkuliahan Kalkulus Integral tahun akademik 2017/2018 diminta untuk mengisi angket efikasi diri, (3) dilakukan analisis terhadap hasil angket tersebut, (4) dilakukan perangkingan terhadap hasil angket untuk menentukan siapa saja mahasiswa yang akan diwawancarai, (5) dipilih 6 mahasiswa, terdiri atas masing-masing 2 mahasiswa dengan efikasi diri tinggi, sedang, dan rendah untuk diwawancarai agar memperoleh data lebih mendalam mengenai efikasi diri, (6) dilakukan pengecekan antara hasil pengamatan dan hasil angket dengan hasil wawancara terhadap mahasiswa yang menjadi subjek penelitian.

Data dalam penelitian ini berupa hasil respon mahasiswa yang dikumpulkan melalui angket efikasi diri, data hasil wawancara dengan beberapa mahasiswa, serta data hasil pengamatan terhadap kegiatan perkuliahan mahasiswa di kelas dan tugas-tugas mahasiswa. Data kuantitatif diperoleh dari pengisian angket efikasi diri, sementara data kualitatif diperoleh dari hasil pengamatan dan wawancara.

Instrumen pengumpulan data terdiri dari angket efikasi diri serta pedoman wawancara. Angket efikasi diri dan pedoman wawancara divalidasi oleh dua orang ahli kemudian direvisi berdasarkan masukan dari validator. Berdasarkan hasil validasi isi diperoleh hasil bahwa angket efikasi diri dan pedoman wawancara layak digunakan. Berdasarkan hasil perhitungan diperoleh bahwa keofisien reliabilitas angket efikasi diri adalah 0,763. Ini menunjukkan bahwa angket efikasi diri telah baik karena menurut Gable (1986, p. 147) instrumen afektif yang baik memiliki reliabilitas sekurang-kurangnya 0,7 .

Teknik pengumpulan data dilakukan dengan memberikan angket efikasi diri kepada subjek penelitian. Selanjutnya dari hasil angket tersebut dikumpulkan data lebih mendalam mengenai efikasi diri mahasiswa dengan cara wawancara terhadap 6 subjek penelitian.

Teknik analisis data dilakukan dengan tahapan-tahapan berikut (Sugiyono, 2008): Pertama, reduksi data: dilakukan analisis terhadap hasil angket efikasi diri, selanjutnya dirangking untuk menentukan siapa saja subjek penelitian yang akan diwawancarai. Analisis hasil angket efikasi diri dilakukan dengan mengonversi data kuantitatif skala lima dari menjadi data kualitatif dengan acuan dari Azwar (1996, p. 163) pada Tabel 1.

Tabel 1. Konversi Data Angket Efikasi Diri

\begin{tabular}{cc}
\hline Interval Skor & Kriteria \\
\hline$X>\bar{x}_{\imath}+1,5 S B_{i}$ & Sangat tinggi \\
$\overline{x_{l}}+0,5 S B_{i}<X \leq \bar{x}_{\iota}+1,5 S B_{i}$ & Tinggi \\
$\overline{x_{l}}-0,5 S B_{i}<X \leq \bar{x}_{\iota}+0,5 S B_{i}$ & Sedang \\
$\overline{x_{l}}-1,5 S B_{i}<X \leq \bar{x}_{\iota}-0,5 S B_{i}$ & Rendah \\
$X \leq \bar{x}_{\iota}-1,5 S B_{i}$ & Sangat rendah \\
\hline
\end{tabular}

Keterangan:

$\bar{x}_{i}=$ rerata skor ideal $=\frac{1}{2}$ (skor maksimum ideal + skor minimum ideal) 
Jurnal Riset Pendidikan Matematika, 5 (2), 2018 - 184

Mega Eriska Rosaria Purnomo, Christina Kartika Sari, Sri Rejeki, Isnaeni Umi Machromah

$\mathrm{SBi}=$ simpangan baku ideal $=\frac{1}{6}$ (skor maksimum ideal - skor minimum ideal)

$X=$ total skor aktual

Kedua, penyajian data: hasil pengamatan dan hasil angket terhadap subjek penelitian yang akan diwawancarai disajikan sebagai bahan wawancara, hasil wawancara dengan 6 subjek penelitian yang telah direkam juga turut disajikan; Ketiga, verifikasi: dilakukan dengan methodological triangulation yaitu melakukan pengecekan antara hasil pengamatan dan hasil angket dengan hasil wawancara.

\section{HASIL DAN PEMBAHASAN}

\section{Deskripsi Hasil}

Data efikasi diri diperoleh melalui angket efikasi diri. Angket ini terdiri dari 27 butir pernyataan positif dan negatif dengan skala yang digunakan adalah skala Likert terdiri dari 5 pilihan jawaban. Butir pernyataan 1 sampai dengan 22 menggunakan lima pilihan jawaban yaitu: selalu, sering, kadang-kadang, jarang, serta tidak pernah. Sementara butir pernyataan 3 sampai dengan 27 menggunakan pilihan jawaban: sangat setuju, setuju, ragu-ragu, tidak setuju, dan sangat tidak setuju.

Berdasarkan Tabel 1, maka skor minimal ideal, skor maksimal ideal, rata-rata ideal, dan simpangan baku ideal dari angket efikasi diri disajikan pada Tabel 2.

Tabel 2. Skor Minimal Ideal, Skor Maksimal Ideal, Rata-rata Ideal, dan Simpangan Baku Ideal Angket Efikasi Diri

\begin{tabular}{cc}
\hline Keterangan & Nilai \\
\hline Banyak item & 27 \\
Skor minimal ideal & 27 \\
Skor maksimal ideal & 135 \\
Rata-rata ideal & 81 \\
Simpangan baku ideal & 18 \\
\hline
\end{tabular}

Selanjutnya, kriteria untuk hasil angket efikasi diri disajikan pada Tabel 3.

Tabel 3. Kriteria Data Angket Efikasi Diri

\begin{tabular}{cc}
\hline Interval Skor & Kriteria \\
\hline$X>108$ & Sangat tinggi \\
$90<X \leq 108$ & Tinggi \\
$72<X \leq 90$ & Sedang \\
$54<X \leq 72$ & Rendah \\
$X \leq 54$ & Sangat rendah \\
\hline
\end{tabular}

Tabel 4 menunjukkan data hasil angket efikasi diri.
Tabel 4. Data Angket Efikasi Diri

\begin{tabular}{cc}
\hline Keterangan & Nilai \\
\hline Skor tertinggi & 110 \\
Skor terendah & 65 \\
Rata-rata & 89 \\
\hline
\end{tabular}

Lebih lanjut, berdasarkan angket efikasi diri yang diisi oleh 43 mahasiswa, diperoleh hasil bahwa 2\% mahasiswa memiliki efikasi diri sangat tinggi, $40 \%$ tinggi, $51 \%$ sedang, sisanya 7\% mahasiswa dengan efikasi diri rendah. Data tersebut disajikan dalam Gambar 1.

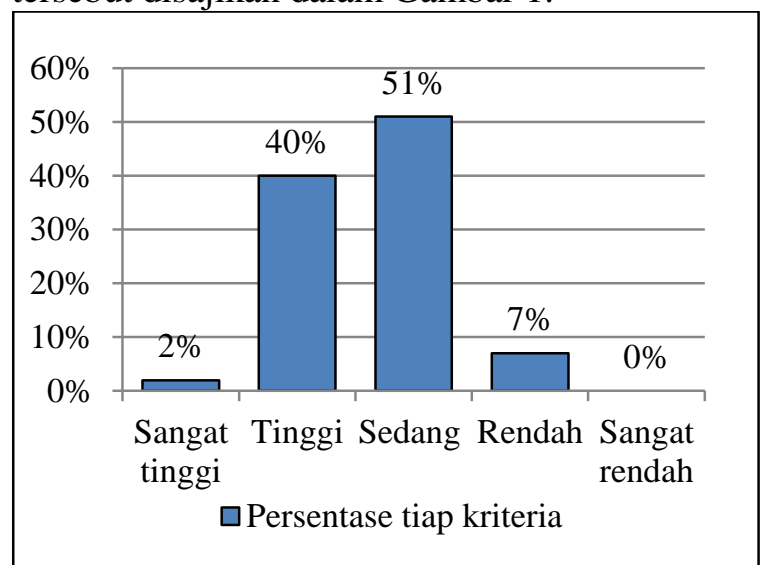

Gambar 1. Persentase Hasil Angket Efikasi Diri pada Tiap Kriteria

Berdasarkan hasil angket tersebut, selanjutnya dipilih 6 mahasiswa, terdiri atas masingmasing 2 mahasiswa dengan efikasi diri tinggi, sedang, dan rendah untuk diwawancarai agar memperoleh data lebih mendalam mengenai efikasi diri. Mahasiswa yang memiliki efikasi diri tinggi sebut saja $R_{1}$ dan $R_{2}$. Mahasiswa dengan efikasi diri sedang sebut saja $R_{3}$ dan $R_{4}$. Kemudian mahasiswa dengan efikasi diri rendah adalah $\mathrm{R}_{5}$ dan $\mathrm{R}_{6}$.

Hasil wawancara dengan $\mathrm{R}_{1}$ meliputi halhal sebagai berikut. Pertama, $\mathrm{R}_{1}$ belum mampu bila harus mempelajari materi Kalkulus Integral yang sulit secara mandiri. Cara belajar yang digunakan $R_{1}$ apabila menemui materi yang sulit adalah dengan berdiskusi kelompok atau belajar bersama dengan teman sejawatnya. Kedua, $\mathrm{R}_{1}$ mampu menyelesaikan soal-soal Kalkulus Integral yang diberikan, tidak merasa putus asa jika menemui soal sulit. Teknik yang sering digunakan oleh $\mathrm{R}_{1}$ adalah dengan searching penyelesaian soal-soal serupa, kemudian memahami penyelesaiannya. Setelah paham, selanjutnya mencoba mencari solusi dari soal yang diberikan. Jika $\mathrm{R}_{1}$ belum berhasil menemukan solusi, maka hal lain yang biasa dilakukan adalah bertanya kepada kakak tingkat atau dosen. Ketiga, $\mathrm{R}_{1}$ mampu menyelesaikan dan mengumpulkan tugas-tugas 
perkuliahan tepat waktu, meskipun waktu pengerjaan tugas tersebut terbatas. Keempat, $\mathrm{R}_{1}$ tidak optimis untuk mencapai target yang telah ia tetapkan yaitu nilai A. Berkaca pada usaha belajar yang dilakukan, $\mathrm{R}_{1}$ merasa bahwa ia hanya akan memperoleh nilai $\mathrm{B}$ pada perkuliahan Kalkulus Integral. Kelima, $\mathrm{R}_{1}$ merasa bahwa usahanya belum maksimal pada perkuliahan ini. Hal ini karena $\mathrm{R}_{1}$ mengalami kesulitan pembagian waktu belajar akibat adanya kegiatan praktikum yang cukup ekstrim. Sehingga, $\mathrm{R}_{1}$ kekurangan waktu untuk berlatih menyelesaikan soalsoal. Berikut beberapa kutipan wawancara dengan $\mathrm{R}_{1}$.

“... saya kurang yakin akan mendapat nilai $A$ pada mata kuliah ini, dapat B saya sudah bersyukur, mengingat usaha yang saya lakukan juga belum terlalu maksimal ..."

“... saya merasa pada semester ini kegiatan praktikum sangat padat ... hal tersebut menyebabkan saya kesulitan dalam membagi waktu, sehingga alokasi yang saya gunakan untuk belajar dan berlatih menyelsaikan soalsoal kalkulus juga belum maksimal ..."

Hasil wawancara dengan $\mathrm{R}_{2}$ meliputi halhal sebagai berikut. Pertama, $\mathrm{R}_{2}$ belum mampu untuk mempelajari materi Kalkulus Integral yang sulit secara mandiri. Strategi belajar yang digunakan $\mathrm{R}_{2}$ bila menemui materi yang sulit adalah dengan mengamati tipe-tipe penyelesaian soal dan bertanya kepada dosen. $R_{2}$ merasa jika sudah mendapat sedikit petunjuk dari dosen, ia akan lebih mudah untuk memahami materi. Kedua, $\mathrm{R}_{2}$ mampu menyelesaikan soal-soal Kalkulus Integral yang diberikan. Namun, jika menemui soal sulit, $\mathrm{R}_{2}$ merasa terkejut, akan tetapi tetap berusaha mencari penyelesaiannya. Teknik yang sering digunakan oleh $\mathrm{R}_{2}$ adalah dengan bertanya kepada teman yang lebih pintar. Selanjutnya jika teman yang lebih pintar belum berhasil memecahkan soal sulit tersebut, barulah $\mathbf{R}_{2}$ bertanya kepada dosen. Ketiga, $\mathrm{R}_{2}$ mampu menyelesaikan dan mengumpulkan tugas-tugas perkuliahan tepat waktu, sekalipun itu adalah tugas yang sulit. Selain itu, semua tugas yang dikumpulkan telah dipahami $\mathrm{R}_{2}$ dengan baik. Keempat, $\mathrm{R}_{2}$ merasa bahwa ia belum berusaha maksimal pada perkuliahan Kalkulus Integral. Ini disebabkan begitu banyak tugas yang diberikan oleh para dosen sehingga pikirannya bercabang-cabang tidak bisa fokus. Kelima, meskipun demikian, $\mathrm{R}_{2}$ tetap optimis untuk mencapai hasil memuaskan pada perkuliahan Kalkulus Integral. $\mathbf{R}_{2}$ berusaha mengambil point lebih melalui aktif saat proses perkuliahan di kelas dengan cara berusaha menjelaskan materi kepada temannya yang belum paham serta aktif menyelesaikan latihan soal yang diberikan oleh dosen di papan tulis tanpa harus ditunjuk oleh dosen. Berikut beberapa kutipan wawancara dengan $\mathrm{R}_{2}$.

“... saya merasa terlalu banyak tugas yang diberikan oleh dosen, hamper semua mata kuliah tugasnya banyak ... ini menyebabkan saya tidak bisa fokus ..."

“... kalau masalah nilai, saya tetap optimis akan mendapatkan nilai yang maksimal, meskipun belajar saya kurang maksimal, saya akan berusaha untuk berperan aktif selama perkuliahan ... aktif mengerjakan soal di depan ... bila perlu tanpa harus ditunjuk langsung oleh ..."

Hasil wawancara dengan $\mathrm{R}_{3}$ meliputi halhal sebagai berikut. Pertama, $\mathrm{R}_{3}$ mampu mempelajari materi Kalkulus Integral secara mandiri. Akan tetapi, semakin hari $\mathrm{R}_{3}$ merasa bahwa materi perkuliahan semakin sulit. Oleh karena itu, untuk mengatasi hal tersebut $\mathrm{R}_{3}$ berupaya lebih sering membaca buku atau sumber belajar lain dan aktif bertanya kepada teman yang lebih mengetahui. Kedua, $\mathrm{R}_{3}$ mampu dan tak putus asa untuk menyelesaikan permasalahan Kalkulus Integral yang diberikan. Strategi yang digunakan oleh $R_{3}$ adalah dengan memahami penyelesaian dari contoh-contoh soal yang telah diajarkan, dilanjut dengan mencari penyelesaian dari permasalahan serupa di internet kemudian baru mencoba untuk memecahkannya. Jika ternyata mengalami kebuntuan, maka hal yang dilakukan adalah dengan bertanya kepada teman yang dirasa lebih pintar. Ketiga, $\mathrm{R}_{3}$ menyelesaikan dan mengumpulkan tugas-tugas perkuliahan dengan tepat waktu. Keempat, $\mathrm{R}_{3}$ merasa usaha belajar yang dilakukan pada perkuliahan Kalkulus Integral masih kurang dan belum optimal karena sulit membagi waktu belajar akibat kegiatan organisasi, praktikum, serta berbagai macam tugas dari mata kuliah lain. Kelima, meskipun demikian, $\mathrm{R}_{3}$ tetap optimis untuk mencapai hasil baik pada perkuliahan Kalkulus Integral. $R_{3}$ berusaha mengambil kesempatan dengan memperbanyak intensitas belajar dan berlatih soal pada saat-saat mejelang UTS dan UAS. Berikut beberapa kutipan wawancara dengan $\mathrm{R}_{3}$.

\footnotetext{
“... kendala yang saya hadapi adalah sulitnya membagi waktu ... saya aktif di organisasi, sehingga otomatis banyak kegiatan organisasi yang juga saya ikuti ... praktikum juga sangat padat, belum lagi tugas dari mata
} 
kuliah lain yang juga banyak ... saya benarbenar merasa kesulitan dalam membagi waktu untuk hal-hal tersebut ..."

“... meskipun saya merasa selama perkuliahan usaha saya belum terlalu maksimal, tetapi saya akan tetap berusaha dan tetap optimis mendapatkan nilai yang maksimal ... mungkin nanti menjelang UTS dan UAS saya akan memperbanyak intensitas belajar saya, serta mengurangi aktivitas di organisasi ..."

Hasil wawancara dengan $\mathrm{R}_{4}$ meliputi halhal sebagai berikut. Pertama, $\mathrm{R}_{4}$ belum mampu mempelajari materi Kalkulus Integral yang sulit secara mandiri karena materi dasar belum dikuasai $\mathrm{R}_{4}$ dengan baik. Untuk mengatasi hal tersebut $\mathrm{R}_{4}$ sering meminta belajar bersama dengan teman yang lebih pandai. Kedua, $\mathrm{R}_{4}$ tidak putus asa dalam menyelesaikan permasalahan Kalkulus Integral yang diberikan. Strategi yang digunakan oleh R4 jika tidak dapat menyelesaikan soal sulit adalah bertanya kepada teman yang dirasa lebih pintar. Ketiga, $\mathrm{R}_{4}$ menyelesaikan dan mengumpulkan tugas-tugas perkuliahan dengan tepat waktu. Keempat, $\mathrm{R}_{4}$ merasa belum belajar maksimal pada perkuliahan Kalkulus Integral karena waktu belajar yang ada digunakan untuk menyelesaikan tugas-tugas dari mata kuliah lain. Kelima, berkaca pada usaha yang telah dilakukan, $\mathrm{R}_{4}$ tidak optimis untuk mencapai hasil optimal pada perkuliahan Kalkulus Integral. Berikut beberapa kutipan wawancara dengan $\mathrm{R}_{4}$.

“... terlalu banyak tugas, hampir semua mata kuliah tugasnya banyak ... susah untuk fokus ke salah satu mata kuliah, karena banyak tanggungan lain yang juga harus diselesaikan, jadi dalam mengikuti perkuliahan saya merasa usaha saya belum maksimal ..."

“... saya tetap yakin dan akan berusaha agar nanti nilai saya maksimal, meskipun harus saya akui usaha saya dalam perkuliahan ini belum maksimal, tapi saya harus tetap berusaha ..."

Hasil wawancara dengan $\mathrm{R}_{5}$ meliputi halhal sebagai berikut. Pertama, $\mathrm{R}_{5}$ belum mampu mempelajari materi Kalkulus Integral yang sulit secara mandiri karena materi prasyarat belum dipahami dengan baik. $R_{5}$ membutuhkan panduan dari dosen untuk membimbingnya dalam memahami materi. Selain itu, $\mathrm{R}_{5}$ hanya dapat mempelajari materi jika berada pada mood yang baik. Untuk mengatasi hal tersebut, strategi yang dilakukan oleh $\mathrm{R}_{5}$ adalah belajar bersama teman yang lebih pandai. Kedua, jika di awal $\mathrm{R}_{5}$ telah menemui soal sulit, maka $\mathrm{R}_{5}$ cenderung merasa putus asa untuk menyelesaikannya, meskipun mungkin di akhir soal yang diberikan lebih sederhana. Oleh karena itu, strategi yang digunakan oleh $\mathrm{R}_{5}$ adalah belajar dengan menyelesaikan soal-soal yang mudah terlebih dahulu kemudian berlanjut soal yang sulit. Ketiga, $\mathrm{R}_{5}$ menyelesaikan dan mengumpulkan tugas-tugas perkuliahan dengan tepat waktu. Keempat, $\mathrm{R}_{5}$ belum belajar maksimal pada perkuliahan Kalkulus Integral karena $\mathrm{R}_{5}$ memiliki kebiasaan belajar hanya sesuai dengan kebutuhan dan jika mood sedang baik. Selain itu, $R_{5}$ mengaku jika semangat belajarnya pada semester genap ini menurun drastis jika dibandingkan dengan saat semester gasal dulu. Kelima, berkaca pada usaha yang telah dilakukan, $\mathrm{R}_{5}$ tidak yakin untuk mencapai hasil optimal pada perkuliahan ini. Berikut beberapa kutipan wawancara dengan $\mathrm{R}_{5}$.

“... jujur saya merasa motivasi saya dalam mengikuti kuliah di semester ini tidak seperti semester kemaren ... ya ini karena kebiasaan saya sih yang hanya mau belajar sesuai dengan kebutuhan saja, belum lagi kalo lagi nggak 'mood' saya tambah kurang semangat untuk belajar, termasuk dalam perkuliah kalkulus integral ..."

“... saya sudah pasrah, apapun nilainya nanti akan saya terima, mengingat usaha saya juga yang tidak maksimal selama mengikuti perkuliahan ini ..."

Hasil wawancara dengan $\mathrm{R}_{6}$ meliputi halhal sebagai berikut. Pertama, $\mathrm{R}_{6}$ belum mampu mempelajari materi Kalkulus Integral yang sulit secara mandiri karena $\mathrm{R}_{6}$ belum memahami materi dasar dengan baik. Strategi yang dilakukan oleh $\mathrm{R}_{6}$ adalah meminta diajari kepada teman yang lebih pintar. Kedua, $\mathrm{R}_{6}$ merasa putus asa jika menjumpai permasalahan Kalkulus Integral yang rumit. Oleh karena itu, $\mathrm{R}_{6}$ sering bertanya kepada teman yang dirasa lebih pintar untuk membantunya dalam menemukan solusi. Ketiga, $\mathrm{R}_{6}$ menyelesaikan dan mengumpulkan tugas-tugas perkuliahan dengan tepat waktu. Keempat, $\mathrm{R}_{6}$ belum belajar maksimal pada perkuliahan Kalkulus Integral karena keteteran untuk membagi waktu belajar akibat banyaknya tugas-tugas dari mata kuliah lain serta kegiatan organisasi. Kelima, melihat usaha yang telah dilakukan, $\mathrm{R}_{6}$ tidak optimis akan mencapai hasil optimal pada perkuliahan ini. Berikut beberapa kutipan wawancara dengan $\mathrm{R}_{6}$. 
Jurnal Riset Pendidikan Matematika, 5 (2), 2018 - 187

Mega Eriska Rosaria Purnomo, Christina Kartika Sari, Sri Rejeki, Isnaeni Umi Machromah

“... saya merasa dalam perkuliahan kalkulus integral ini usaha saya sangat belum maksimal ... jujur saya merasa keteteran untuk membagi waktu belajar, tugas-tugas dari mata kuliah lain banyak, belum lagi kegiatan-kegiatan organisasi, susah untuk membagi waktunya ..."

“... karena usaha saya yang kurang maksimal tersebut, saya nggak yakin akan mendapat nilai maksimal, asal lulus saja dari mata kuliah ini saya sudah bersyukur ..."

\section{Pembahasan}

Berdasarkan hasil angket efikasi diri, terlihat bahwa efikasi mahasiswa pada perkuliahan Kalkulus Integral mayoritas berada pada kategori sedang. Temuan ini menguatkan hasil penelitian Utami dan Wutsqa (2017, p. 171) yang menyatakan bahwa secara keseluruhan, rata-rata efikasi diri siswa di SMP Negeri Ciamis berada pada kriteria sedang. Temuan ini dapat menjadi rujukan bagi dosen, menyadari pentingnya efikasi diri pada mahasiswa karena berpotensi untuk menghasilkan mahasiswa dengan kemampuan matematis baik.

Berdasarkan hasil wawancara diperoleh fakta temuan bahwa mahasiswa dengan tingkat efikasi diri tinggi, sedang, dan rendah belum mampu bila harus mempelajari materi Kalkulus Integral yang sulit secara mandiri. Mereka masih memerlukan bantuan dari teman yang lebih pintar ataupun dosen. Materi Kalkulus Integral di perguruan tinggi memiliki tingkat kompleksitas yang lebih tinggi dibandingkan dengan materi integral saat di bangku SMA/SMK. Matematika sekolah dengan matematika perguruan tinggi tentu saja memiliki karakteristik berbeda. Selain itu, semakin banyaknya tugas menjadikan mahasiswa kesulitan untuk membagi waktu belajar.

Menurut Vygotsky (Bature \& Jibrin, 2011, p. 277), proses edukasi sebaiknya didasarkan pada kemampuan kolaborasi anatara guru dan pembelajar baik dalam aktivitas individual maupun maupun kolaboratif dimana keduanya merupakan pemimpin dalam kelas. Lebih lanjut, Vygotsky menyatakan bahwa jalan masuk pengetahuan matematis adalah melalui komunikasi. Pada perspektif ini, pembelajaran melibatkan dua bidang yaitu bidang sosial melalui interaksi dengan orang lain dan internal, bidang psikologis. Oleh sebab itu, diskusi menjadi bagian penting dari pembelajaran dibandingkan dengan guru mentransmisikan suatu pengetahuan (Chambers, 2008, p. 102).
Dengan demikian, aktivitas perkuliahan Kalkulus Integral di kelas seyogyanya melibatkan interaksi antara dosen dan mahasiswa. Ada kalanya mahasiswa bekerja secara individu, bekerja bersama teman sebaya, dan ada kalanya juga mendapatkan bimbingan, arahan dan support dari dosen untuk memudahkan dalam memahami materi. Penggunaan software matematika pun dapat dilakukan oleh dosen untuk mendukung pembelajaran Kalkulus Integral di kelas. Software matematika mampu memberikan visualisasi, menggambar berbagai grafik fungsi, serta mengecek jawaban akhir mahasiswa Menurut (Sari, Machromah, \& Safika, 2017, p. 65) penggunaan software matematika harus diimbangi dengan penjelasan rinci terkait konsep-konsep materi. Software matematika dapat berperan sebagai pendukung pembelajaran kalkulus.

Lebih lanjut, mahasiswa dengan tingkat efikasi diri tinggi dan sedang tidak putus asa dalam menyelesaikan permasalahan Kalkulus Integral. Bagi mahasiswa yang memiliki pemahaman materi baik, berbagai contoh soal yang telah diajarkan, beragam penyelesaian soal serupa di di internet sangat membantu mahasiswa dalam memecahkan masalah. Menurut temuan penelitian Purnomo, \& Machromah (2017, p. 416) terdapat mahasiswa yang menyelesaikan masalah dengan menuliskan jawaban dengan jawaban dari contoh soal yang pernah diberikan pada perkuliahan Geometri Ruang. Padahal, contoh soal yang diberikan di kelas jelas berbeda dari soal yang diberikan. Hal ini karena mahasiswa tidak memahami materi dan belajar dengan mengingat jawaban dari latihan soal yang pernah diberikan, bukan melalui pemahaman.

Sementara itu, mahasiswa dengan tingkat efikasi diri rendah mengalami keputusasaan dalam menghadapi permasalahan Kalkulus Integral. Keputusasaan yang dihadapi oleh mahasiswa berpengaruh terhadap pencapaian prestasi mereka pada perkuliahan Kalkulus Integral. Penelitian oleh Pimta, Tayruakham, dan Nuangchalerm (2009) menyatakan bahwa efikasi diri dan motivasi merupakan faktor tidak langsung yang mempengaruhi kemampuan pemecahan masalah.

Terkait dengan tugas, mahasiswa dengan efikasi diri tinggi, sedang, dan rendah mampu menyelesaikan tugas dan mengumpulkannya tepat waktu. Berdasarkan hasil tugas tersebut, masih terdapat mahasiswa yang salah dalam melakukan teknik substitusi integral. Mahasiswa mengganti variabel awal dengan variabel baru, namun masih menyisakan variabel awal. Temuan 
ini serupa dengan studi pendahuluan yang telah dilakukan oleh (Machromah, Purnomo, Febriyanti, \& Rahmawati, 2017, p. 365) yang menyatakan bahwa mahasiswa prodi pendidikan matematika salah menerapkan konsep pengintegralan dengan teknik substitusi integral. Beberapa mahasiswa menggantikan variabel awal dengan variabel baru tetapi masih menyisakan variabel awal, sehingga pada integran terdapat variabel yang berbeda yang saling menggantikan dan mahasiswa melakukan kesalahan dengan mengeluarkan salah satu variabel dari bentuk integral.

Berkaitan dengan keyakinan atas usaha yang telah dilakukan dan kemampuan untuk mencapai target prestasi pada perkuliahan Kalkulus Integral, mahasiswa dengan efikasi diri tinggi, sedang, dan rendah mengemukakan bahwa usaha belajar yang dilakukan belum optimal dengan berbagai macam penyebab. Akibatnya, mahasiswa tersebut tidak yakin mampu mencapai prestasi belajar yang ditargetkan, terkecuali R2. $\mathrm{R} 2$ yakin untuk memperolah hasil terbaik karena ia berusaha aktif saat proses perkuliahan di kelas dengan cara berusaha menjelaskan materi kepada temannya yang belum paham serta aktif menyelesaikan latihan soal yang diberikan oleh dosen di papan tulis tanpa harus ditunjuk oleh dosen.

\section{SIMPULAN}

Berdasarkan hasil dan pembahasan, dapat disimpulkan hal-hal berikut: (1) $2 \%$ mahasiswa memiliki efikasi diri sangat tinggi, $40 \%$ tinggi, $51 \%$ sedang, sisanya $7 \%$ mahasiswa dengan efikasi diri rendah dengan rata-rata efikasi diri mahasiswa pada perkuliahan Kalkulus Integral sebesar 89 yang berada pada kategori sedang; (2) mahasiswa dengan efikasi diri tinggi dan sedang tidak putus asa menyelesaikan permasalahan Kalkulus Integral, sedangkan mahasiswa dengan efikasi diri rendah putus asa saat menghadapi permasalahan tersebut, (3) mahasiswa dengan tingkat efikasi diri tinggi, sedang, dan rendah belum mampu mempelajari materi sulit Kalkulus Integral secara mandiri. Akan tetapi, mereka mampu menyelesaikan tugas dan mengumpulkannya tepat waktu; (4) usaha belajar mereka belum optimal dengan berbagai macam penyebab sehingga mereka tidak yakin mampu mencapai prestasi belajar yang ditargetkan, terkecuali dua mahasiswa dengan tingkat efikasi diri tinggi dan sedang.

\section{DAFTAR PUSTAKA}

Azwar, S. (1996). Tes prestasi fungsi pengembangan pengukuran prestasi belajar. Yogyakarta: Pustaka Pelajar.

Bature, I. J., \& Jibrin, A. G. (2015). The perception of preservice mathematics teachers on the role scaffolding in achieving quality mathematics classroom instruction. International Journal of Education in Mathematics, Science and Technology, 3(4), 275-287.

Chambers, P. (2008). Teaching mathematics developing as a reflective secondary teacher. London: SAGE Publications.

Gable, R. K. (1986). Instrument development in the affective domain. New York, NY: Springer.

Irwansyah, B. (2013). Self-efficacy mahasiswa prodi PMA dalam pembelajaran kalkulus. Logaritma, 1(2), 115-125.

Jaafar, W. M. W., \& Ayub, A. F. M. (2010). Mathematics self-efficacy and metacognition among university students. Procedia Social and Behavioral Sciences, 8, 519-524.

Machromah, I. U., Purnomo, M. E. R., Febriyanti, K., Rahmawati, H. E. B. (2017). Arithmatics skill: Kesulitan utama mahasiswa dalam menyelesaikan soal kalkulus integral. Prosiding, Seminar Matematika dan Pendidikan Matematika UNY 2017 yang diselenggarakan oleh FMIPA UNY, tanggal 11 November 2017. Yogyakarta: Universitas Negeri Yogyakarta.

Margolis, H., \& McCabe, P. P. (2006). Improving self-efficacy and motivation: What to do, what to say. Intervention in School and Clinic, 41(4), 218-227.

Mercer, S. (2011). Towards an understanding of language learner self-concept. London, UK: Springer.

Motlagh, S. E., Amrai, K., Yazdani, M. J., Abderahim, H. A., \& Sauri, H. (2011). The relationship between self-efficacy and academic achievement in high school students. Procedia Social and Behavioral Sciences, 15, 765-768.

Pimta, S., Tayruakham, S., \& Nuangchalerm, P. (2009). Factor influencing mathematic problem solving ability of sixth grade 
students. Journal of social sciences, 5(4), 381-385.

Purnomo, M. E. R., \& Machromah, I. U. (2017). Solid geometry learning: Student errors in solving solid geometry problems at university level. Jurnal Daya Matematis, 5(3), 408-418.

Putri, U. H., Mardiyana, M., \& Saputro, D. R. S. (2017). How to analyze the students' thinking levels based on SOLO taxonomy? IOP Conference Series: Journal of Physics, 895, 1-8.

Putri, R., \& Santosa, R. (2015). Keefektifan strategi REACT ditinjau dari prestasi belajar, kemampuan penyelesaian masalah, koneksi matematis, self-efficacy. Jurnal Riset Pendidikan Matematika, 2(2), 262-272.

doi:https://doi.org/10.21831/jrpm.v2i2.73 45

Sari, C. K., Machromah, I. U., \& Safika, K. N. S (2017). Pemanfaatan teknologi dalam pembelajaran kalkulus: Mendukung atau sia-sia? Prosiding, Seminar Nasional Kedua Pendidikan Berkemajuan dan Menggembirakan (The Second Progressive and Fun Education Seminar) yang diselenggrakana oleh, tanggal 3 Agustus 2017. Mataram: ALPTK PTM, Universitas Muhammadiyah Mataram.

Schunk, D. H. (2012). Learning theories (6th ed.). Boston, MA: Pearson Education.

Sevimli, E. (2016). Do calculus students demand technology integration into learning environment? Case of instructional differences. International Journal of Educational Technology in Higher Education, 13(37), 1-18.

Sopiyanti, F. (2011). Pengaruh self-efficacy terhadap penyesuaian akademik mahasiswa. Psympathic, Jurnal Ilmiah Psikologi, IV(1), 289-304.

Sugiyono. (2008). Metode penelitian pendidikan. Bandung: Alfabeta.

Suryadi, B. \& Santoso, T. I. (2017). Self-efficacy, adversity quotient, and students' achievement in mathematics. International Education Studies, 10(10), 12-19.

Urdan, T., \& Pajares, F. (2006). Selfefficacy beliefs of adolescents. Greenwich, CT: Information Age Publishing

Utami, R., \& Wutsqa, D. (2017). Analisis kemampuan pemecahan masalah matematika dan self-efficacy siswa SMP negeri di Kabupaten Ciamis. Jurnal Riset Pendidikan Matematika, 4(2), 166-175. doi:https://doi.org/10.21831/jrpm.v4i2.14 897

Wijaya, I. P., \& Pratitis, N. T. (2012). Efikasi diri akademik, dukungan sosial orangtua dan penyesuaian diri mahasiswa dalam perkuliahan. Jurnal Persona, 1(1), 40-52.

Woolfolk, A. (2007). Education psychology $\left(10^{\text {th }}\right.$ ed.). Boston, MA: Pearson Education, Inc.

Yusuf, M. (2011). The impact of self-efficacy, achievement motivation, and selfregulated learning strategies on students' academic achievement. Procedia Social and Behavioral Sciences, 15, 2623-2626. 